ISSN: 2362-1303 (Paper) | eISSN: 2362-1311(Online)

JOURNAL OF ADVANCED ACADEMIC RESEARCH (JAAR)

July 2015

\title{
Impact of Climate Change on Land and Water Management: The Case of Nepal, India and Bangladesh
}

\author{
Krishna Kumar Shrestha ${ }^{1} \&$ Prof. Dr. Tatwa P. Timsina ${ }^{2}$ \\ ${ }^{1} \mathrm{PhD}$ Scholar, Mewar University, Rajasthan, India \\ ${ }^{2}$ Professor, Patan Multiple Campus, TU, Nepal
}

Corresponding Author

Krishna Kumar Shrestha

kks010@ hotmail.com

\begin{abstract}
Agriculture is the backbone of economic development of country like Nepal, India and Bangladesh. Quantity and quality of production depends on quality of soils, irrigation facilities, quality of seeds, farming methods and time, climate, quality and types of fertilizer and the technologies used. In the recent times, the climate change has been reported to impact highly in the performance of the agriculture sector of these countries. Because of the rise of temperature, there is much concern on food securities and other agricultural issues like the changes in cropping pattern due to changing rainfall pattern thus impacting directly and indirectly to their gross domestic product. The objective of this study was to assess the situations against the climate change perspectives including the soil and water issues and its impacts on agriculture and food security of these communities. It also aimed to examine the local adaptation cases with respect to developing criteria for potential adaptation possibilities at the local community level and to make a comparative study in three locations of South Asia namely Madhuri village, Rupandehi district (foot hills) of Nepal, Vaishali village, Patna State (plains) of India and Harikahali village, Khulna district (sea coast) of Bangladesh. The finding of this study helps to provide policy support in mainstreaming adaptation at the community level in the context of natural resource management for the vulnerable communities of the three locations of SA region, and helps governments, development partners and donors in their planning and implementation of climate change related activities from a long term regional perspectives.
\end{abstract}

\section{KEYWORDS}

Adaptation, three SA countries, small farmers, Climate Change, land and Water management 
ISSN: 2362-1303 (Paper) | eISSN: 2362-1311(Online)

JOURNAL OF ADVANCED ACADEMIC RESEARCH (JAAR)

July 2015

\section{INTRODUCTION}

Agricultural production contributes greatly in the total GDP of these countries. Quantity and quality of production is depended mainly on quality of soils and the irrigation facilities among other factors such as the quality of seeds, farming methods and time, climate, quality and types of fertilizer, other technical supports and the human efforts (Parry, 2007). Of these, the climate change has been reported to impact highly in the performance of the agriculture sector in the recent times. It has resulted in the profound change of the soil and water conditions in these countries. At the local level also, people have been observing in their areas increasing in the earth's temperature, untimely raining, drying of the rivers and lowering of the underground water tables, outbreaks of pests and diseases, change in crops and fruits production patterns, decreasing in quality of soil resulting in fertility decrease and the crop yields, melting of snow and increase in salinity of costal water etc. Their overall effect has been the negative impacts on the agriculture production, food security, human health and that of nature (IPCC, 2007). Some of the global problems of our century are food security, water security, poverty, energy security, economic instability and the climate change.

The effect on the soil and water conditions in the fragile ecosystems of these three countries having higher and lower altitudes is even more precarious. Because of the poor soil and water quality, there is a great concern on agriculture and food security issues. These have resulted in some changes in the cropping pattern as the rainfall pattern is changing. Overall, change in temperature has both direct and indirect impact to the gross domestic product (Bhatta, 2013). The maximum impacts on agriculture and food security have been reported to be in this part of the South Asian region. These three study sites carefully chosen fall under three countries namely Nepal, Indian and Bangladesh ranging from the foot hills of Himalaya to the plains of India and on to the coastal region of Bangladesh. Due to human induced activities the areas are facing destruction in regional ecosystems, habitat and livelihoods of the human being (UNFCCC, 2007, p. 83).

The study provides an opportunity to understand the impacts on agriculture systems through the change in farming scenarios of the areas studied. The study is based on the knowledge, skills and practices of the farming communities of these three countries. As most of the farming in Nepal, India and Bangladesh depends on monsoon, change in climate has enormous impact on the soil water situations and thus on the food security of the small farmers of these regions. The fragile ecosystems of these areas are significantly affected.

Study Areas were carefully chosen and fall under the monsoon corridor of three countries of South Asia namely Madhuri village, Rupandehi district (foot hills) of Nepal, Vaishali village, Patna State (plains) of India and Harikahali village, Khulna district (coastal region) of Bangladesh. South Asia has been reported to be suffering the most from the impacts of the climate change. Among these countries, Bangladesh, Nepal and India are top ranking 
ISSN: 2362-1303 (Paper) | eISSN: 2362-1311(Online)

JOURNAL OF ADVANCED ACADEMIC RESEARCH (JAAR)

July 2015

making the study most practical. Culturally speaking, all these communities are very close to each other in terms of their food habits, social and gender perspectives, farming perception, rural poverty and livelihood options. However, with all these similarities, the locations also show a distinct difference in terms of the impacts of climate change. Nepal has more snow melting due to global warming resulting in soil and water erosions. Indian planes using more green revolution technologies would have degradation of soil and water quality including deepening ground water level. Whereas, the coastal area of Bangladesh distinctly show the sea water rising due to global warming resulting in inland sea water that has caused havoc due to ever increasing salinity problems.

\section{METHOD}

The study was based on the descriptive analysis. In total 420 respondents were selected from Nepal, India and Bangladesh. Small farmers of the communities of the selected sites were selected for the study to explore their opinion about the impact of climate change on agriculture. Self-reported survey questionnaires were administered to collect the quantitative data. Frequency table, cross tab and Chi-square tests were done to analyze the data.

\section{RESULT}

Altogether 420 respondents were selected from the 3 countries; Nepal, India and Bangladesh for this study. In total, $73.6 \%$ male followed by $26.4 \%$ female participated from Nepal, $69.3 \%$ male and $30.7 \%$ female from India and $71.4 \%$ male and $28.6 \%$ female from Bangladesh. Thus the average total for male was $71.4 \%$ and that of female was $28.6 \%$ for all three countries in this study. Majority of respondents i.e. $48.1 \%$ were from the scheduled caste which was $86.4 \%$ in Nepal, $31.4 \%$ in India and $26.4 \%$ in Bangladesh. It was followed by OBC (25.2\%) which was $2.9 \%$ in Nepal, $40.0 \%$ in India and $32.9 \%$ in Bangladesh. The remaining $21.4 \%$ was from the general caste which was $7.9 \%$ in Nepal, $19.9 \%$ in India and $38.6 \%$ in Bangladesh. Only 22 respondents did not mention their caste during the study. Education wise, $73.6 \%$ respondents had secondary or above level education in Nepal followed by $22.1 \%$ from primary and $2.1 \%$ were illiterate and $2.1 \%$ literate. Comparatively, $95.7 \%$ literate and $4.3 \%$ illiterate from Bangladesh and 90.7\% literate and 9.3\% illiterate from India participated in study. Data showed the patriarchy society in all three countries. A total of $73.6 \%$ Male from Nepal, 98.6\% India and 92.9\% from Bangladesh are head of family. Comparatively, more female are head of family in Nepal than in other countries. 
ISSN: 2362-1303 (Paper) | eISSN: 2362-1311(Online)

JOURNAL OF ADVANCED ACADEMIC RESEARCH (JAAR)

\section{Water management related changes:}

Table 1: Water management related changes:

\begin{tabular}{|c|c|c|c|c|c|c|c|}
\hline \multicolumn{7}{|c|}{ Water management related changes } & \multirow{3}{*}{$\begin{array}{c}\text { Pearson } \\
\text { Chi- } \\
\text { Square }\end{array}$} \\
\hline & & & \multicolumn{3}{|c|}{ Address of respondents } & \multirow{2}{*}{ Total } & \\
\hline & & & Nepal & India & Bangladesh & & \\
\hline \multirow{9}{*}{ 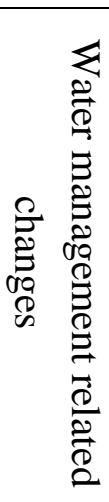 } & & Count & 136 & 21 & 53 & 210 & \multirow{12}{*}{$\begin{array}{c}\text { Value }= \\
296.797 \\
\text { Df }=4 \\
\text { Asymp. } \\
\text { Sig. (2- } \\
\text { sided).000 } \\
\text { (S) }\end{array}$} \\
\hline & No changes & $\%$ within total response & $64.8 \%$ & $10.0 \%$ & $25.2 \%$ & $100.0 \%$ & \\
\hline & & $\%$ within address & $97.1 \%$ & $15.0 \%$ & $37.9 \%$ & $50.0 \%$ & \\
\hline & & Count & 4 & 119 & 48 & 171 & \\
\hline & One change & $\%$ within total response & $2.3 \%$ & $69.6 \%$ & $28.1 \%$ & $100.0 \%$ & \\
\hline & & $\%$ within address & $2.9 \%$ & $85.0 \%$ & $34.3 \%$ & $40.7 \%$ & \\
\hline & \multirow{3}{*}{$\begin{array}{c}\text { Two } \\
\text { changes }\end{array}$} & Count & 0 & 0 & 39 & 39 & \\
\hline & & $\%$ within total response & $0.0 \%$ & $0.0 \%$ & $100.0 \%$ & $100.0 \%$ & \\
\hline & & $\%$ within address & $0.0 \%$ & $0.0 \%$ & $27.9 \%$ & $9.3 \%$ & \\
\hline \multirow{3}{*}{\multicolumn{2}{|c|}{ Total }} & Count & 140 & 140 & 140 & 420 & \\
\hline & & $\%$ within total response & $33.3 \%$ & $33.3 \%$ & $33.3 \%$ & $100.0 \%$ & \\
\hline & & $\%$ within address & $100.0 \%$ & $100.0 \%$ & $100.0 \%$ & $100.0 \%$ & \\
\hline
\end{tabular}

Sources: Field study, 2013

The table 1 shows that in Nepal, a total of $97.1 \%$ of respondents had not made any water management-related changes. And only $2.9 \%$ of respondents reported that they made at least one change in regards of water management. Similarly, in India, $85 \%$ have made one water management related changed whereas $15 \%$ had not made any changes. In Bangladesh, they reported that in total $34.3 \%$ made at least one changes and $27.9 \%$ made two changes. Remaining $37.9 \%$ reported that they had not made any water management related changes

There was significant association $(\mathrm{p}=.000)$ found between the respondents of 3 countries regarding the water management related change.

\section{Access on irrigation facilities for on-farm agriculture}

Table 2: Access on irrigation facilities

\begin{tabular}{|c|c|c|c|c|c|c|c|}
\hline \multicolumn{7}{|c|}{ Access on irrigation facilities } & \multirow{3}{*}{$\begin{array}{c}\text { Pearson } \\
\text { Chi- } \\
\text { Square }\end{array}$} \\
\hline & & & Add & ess of $\mathrm{rt}$ & spondents & & \\
\hline & & & Nepal & India & Bangladesh & Total & \\
\hline \multirow{5}{*}{ 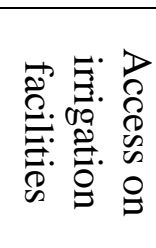 } & \multirow{3}{*}{ Yes } & Count & 102 & 126 & 28 & 256 & \multirow{5}{*}{$\begin{array}{c}\text { Value= } \\
156.620 \\
\text { Df }=2 \\
\text { Asymp. } \\
\text { Sig. (2- }\end{array}$} \\
\hline & & $\%$ within total & $39.8 \%$ & $49.2 \%$ & $10.9 \%$ & $100.0 \%$ & \\
\hline & & $\%$ within address & $72.9 \%$ & $90.0 \%$ & $20.0 \%$ & $61.0 \%$ & \\
\hline & \multirow{2}{*}{ No } & Count & 38 & 14 & 112 & 164 & \\
\hline & & $\%$ within total & $23.2 \%$ & $8.5 \%$ & $68.3 \%$ & $100.0 \%$ & \\
\hline
\end{tabular}

Vol. 2. No. II

www.phdcentre.edu.np 
ISSN: 2362-1303 (Paper) | eISSN: 2362-1311(Online)

JOURNAL OF ADVANCED ACADEMIC RESEARCH (JAAR)

July 2015

\begin{tabular}{|c|c|c|c|c|c|c|c|}
\hline & \% within address & $27.1 \%$ & $10.0 \%$ & $80.0 \%$ & $39.0 \%$ & sided).000 \\
\hline \multirow{3}{*}{ Total } & Count & 140 & 140 & 140 & 420 & \multirow{2}{*}{$(\mathrm{S})$} \\
\cline { 2 - 7 } & \% within total & $33.3 \%$ & $33.3 \%$ & $33.3 \%$ & $100.0 \%$ & \\
\cline { 2 - 7 } & \% within address & $100.0 \%$ & $100.0 \%$ & $100.0 \%$ & $100.0 \%$ & \\
\hline
\end{tabular}

Sources: Field study, 2013

Regarding the access on irrigation facility for on-farm agriculture it was identified that a total of $72.9 \%$ respondents of Nepal reported that they had access on irrigation facilities. This figure was higher i.e. $90 \%$ for India and lower $20 \%$ only in case of Bangladesh.

There was significant association $(\mathrm{p}=.000)$ found between the respondents of 3 countries regarding the access on irrigation facilities.

\section{Types of water sources for agriculture on-farm:}

Table 3: Types of water sources for agriculture

\begin{tabular}{|c|c|c|c|c|c|c|c|}
\hline \multicolumn{7}{|c|}{ Types of water sources for agriculture } & \multirow{3}{*}{$\begin{array}{l}\text { Pearson } \\
\text { Chi- } \\
\text { Square }\end{array}$} \\
\hline & & & \multicolumn{3}{|c|}{ Address of Respondents } & \multirow{2}{*}{ Total } & \\
\hline & & & Nepal & India & Bangladesh & & \\
\hline \multirow{18}{*}{ 总 } & \multirow{3}{*}{$\begin{array}{l}\text { Natural } \\
\text { Irrigation }\end{array}$} & Count & 68 & 17 & 6 & 91 & \multirow{21}{*}{$\begin{array}{c}\text { Value }= \\
337.763 \\
\text { Df }=10 \\
\text { Asymp. } \\
\text { Sig. (2- } \\
\text { sided). } 000 \\
\text { (S) }\end{array}$} \\
\hline & & $\%$ within total & $74.7 \%$ & $18.7 \%$ & $6.6 \%$ & $100.0 \%$ & \\
\hline & & $\%$ within address & $48.6 \%$ & $12.1 \%$ & $4.3 \%$ & $21.7 \%$ & \\
\hline & \multirow{3}{*}{\begin{tabular}{|c|} 
Tanks for \\
water \\
harvesting
\end{tabular}} & Count & 2 & 0 & 4 & 6 & \\
\hline & & $\%$ within total & $33.3 \%$ & $0.0 \%$ & $66.7 \%$ & $100.0 \%$ & \\
\hline & & $\%$ within address & $1.4 \%$ & $0.0 \%$ & $2.9 \%$ & $1.4 \%$ & \\
\hline & \multirow{3}{*}{$\begin{array}{c}\text { Dams or } \\
\text { waterholes }\end{array}$} & Count & 3 & 18 & 4 & 25 & \\
\hline & & $\%$ within total & $12.0 \%$ & $72.0 \%$ & $16.0 \%$ & $100.0 \%$ & \\
\hline & & $\%$ within address & $2.1 \%$ & $12.9 \%$ & $2.9 \%$ & $6.0 \%$ & \\
\hline & \multirow{3}{*}{ Boreholes } & Count & 33 & 76 & 0 & 109 & \\
\hline & & $\%$ within total & $30.3 \%$ & $69.7 \%$ & $0.0 \%$ & $100.0 \%$ & \\
\hline & & $\%$ within address & $23.6 \%$ & $54.3 \%$ & $0.0 \%$ & $26.0 \%$ & \\
\hline & \multirow{3}{*}{$\begin{array}{l}\text { Water } \\
\text { pumps }\end{array}$} & Count & 28 & 15 & 14 & 57 & \\
\hline & & $\%$ within total & $49.1 \%$ & $26.3 \%$ & $24.6 \%$ & $100.0 \%$ & \\
\hline & & $\%$ within address & $20.0 \%$ & $10.7 \%$ & $10.0 \%$ & $13.6 \%$ & \\
\hline & \multirow{3}{*}{$\begin{array}{l}\text { No water } \\
\text { sources } \\
\text { Rainfall } \\
\text { only }\end{array}$} & Count & 6 & 14 & 112 & 132 & \\
\hline & & $\%$ within total & $4.5 \%$ & $10.6 \%$ & $84.8 \%$ & $100.0 \%$ & \\
\hline & & $\%$ within address & $4.3 \%$ & $10.0 \%$ & $80.0 \%$ & $31.4 \%$ & \\
\hline & \multirow{3}{*}{ Total } & Count & 140 & 140 & 140 & 420 & \\
\hline & & $\%$ within total & $33.3 \%$ & $33.3 \%$ & $33.3 \%$ & $100.0 \%$ & \\
\hline & & $\%$ within address & $100.0 \%$ & $100.0 \%$ & $100.0 \%$ & $100.0 \%$ & \\
\hline
\end{tabular}

Sources: Field study, 2013 
ISSN: 2362-1303 (Paper) | eISSN: 2362-1311(Online)

JOURNAL OF ADVANCED ACADEMIC RESEARCH (JAAR) July 2015

Participants of Nepal reported that $48.6 \%$ had natural irrigation sources available followed by $23.6 \%$ with boreholes, $20 \%$ with water pumps, $2.1 \%$ having dams or waterholes, $1.4 \%$ using tanks for water harvesting and only $4.3 \%$ had to dependent on rainfall due to no permanent water sources. Similarly, majority $(54.3 \%)$ respondents of India had boreholes followed by $12.9 \%$ dams and waterholes, $12.1 \%$ with natural irrigation system, $10.7 \%$ with water pumps and only $10 \%$ dependent on rainfall due to no water sources. In Bangladesh, the problem of water sources for on-farm agricultural was found challenging because in total $80 \%$ had no permanent water sources available and so depended on rainfall. It was followed by $10 \%$ water pumps, $4.2 \%$ natural irrigation, $2.9 \%$ dams or waterholes. And 2.9\% were using tanks for water harvesting as the on-farm agricultural water sources using for agricultural purposes only and not for household use.

When three sites were compared, it was found that Nepal had better irrigation facilities than other 2 countries. There was significant association $(p=.000)$ found between the respondents of 3 countries regarding the types of water sources for agriculture.

\section{Soil Management Related Changes}

For the soil management related changes, the respondents were asked if they had made the following behavioral changes:

- Stopped burning;

- Introduced crop cover;

- Introduced ridges or bunds;

- Introduced mulching;

- Introduced terraces;

- Introduced stone lines;

- Introduced contour ploughing;

- Introduced rotations;

- Started using or using more mineral/chemical fertiliser;

- Started using manure/compost.

Table 4: Soil Management Related Changes:

\begin{tabular}{|c|c|c|c|c|c|c|c|}
\hline \multicolumn{7}{|c|}{ Soil management related changes } & \multirow{3}{*}{$\begin{array}{c}\text { Pearson } \\
\text { Chi- } \\
\text { Square }\end{array}$} \\
\hline & & & \multicolumn{3}{|c|}{ Address of Respondents } & \multirow{2}{*}{ Total } & \\
\hline & & & Nepal & India & Bangladesh & & \\
\hline \multirow{4}{*}{ 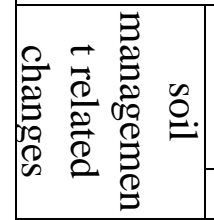 } & \multirow{3}{*}{ No changes } & Count & 9 & 17 & 41 & 67 & \multirow{4}{*}{$\begin{array}{l}\text { Value }= \\
60.597 \\
\text { Df }=4 \\
\text { Asymp. }\end{array}$} \\
\hline & & $\%$ within total & $13.4 \%$ & $25.4 \%$ & $61.2 \%$ & $100.0 \%$ & \\
\hline & & $\%$ within address & $6.4 \%$ & $12.2 \%$ & $29.3 \%$ & $16.0 \%$ & \\
\hline & One change & Count & 79 & 92 & 36 & 207 & \\
\hline
\end{tabular}

Vol. 2. No. II

www.phdcentre.edu.np 
ISSN: 2362-1303 (Paper) | eISSN: 2362-1311(Online)

JOURNAL OF ADVANCED ACADEMIC RESEARCH (JAAR)

July 2015

\begin{tabular}{|c|c|c|c|c|c|c|}
\hline & $\%$ within total & $38.2 \%$ & $44.4 \%$ & $17.4 \%$ & $100.0 \%$ & Sig. (2- \\
\hline & $\%$ within address & $56.4 \%$ & $65.7 \%$ & $25.7 \%$ & $49.3 \%$ & \multirow{7}{*}{$\begin{array}{c}\text { sided) } \\
.000 \\
(\mathrm{~S})\end{array}$} \\
\hline \multirow{3}{*}{$\begin{array}{c}\text { Two or more } \\
\text { changes }\end{array}$} & Count & 52 & 31 & 63 & 146 & \\
\hline & $\%$ within total & $35.6 \%$ & $21.2 \%$ & $43.2 \%$ & $100.0 \%$ & \\
\hline & $\%$ within address & $37.1 \%$ & $22.1 \%$ & $45.0 \%$ & $34.8 \%$ & \\
\hline \multirow{3}{*}{ Total } & Count & 140 & 140 & 140 & 420 & \\
\hline & $\%$ within total & $33.3 \%$ & $33.3 \%$ & $33.3 \%$ & $100.0 \%$ & \\
\hline & $\%$ within address & $100.0 \%$ & $100.0 \%$ & $100.0 \%$ & $100.0 \%$ & \\
\hline
\end{tabular}

Sources: Field study, 2013

It was reported to have been seen in the above table that 79 (56.4\%) households, about half of total surveyed households, had introduced one soil management related practices in Nepal and $52(37.1 \%)$ households cited having made two or more soil management related changes in the last 10 years followed by $9(6.4 \%)$ HHs reported that they had no any soil management related changes done in last 10 years.

In India, majority $(65.7 \%)$ household reported that they had made at least one soil management related change followed by $22.1 \%$ made two or more and $12.2 \%$ made no soil management changes.

In Bangladesh, $45 \%$ had made two or more soil management related changes and $25.7 \%$ had made at least one type of change. $29.3 \%$ had reported that they had made no any changes in last ten years. There was significant association $(p=.000)$ found between the respondents of 3 countries regarding the soil management related changes.

\section{Tree/Agro forestry management related changes}

Table 5: Tree/Agro (Farm) forestry management related changes in Nepal, India and Bangladesh:

\begin{tabular}{|c|c|c|c|c|c|c|c|}
\hline \multicolumn{7}{|c|}{ Tree/Agro (Farm) forestry management related changes } & \multirow{3}{*}{$\begin{array}{c}\text { Pearson } \\
\text { Chi- } \\
\text { Square }\end{array}$} \\
\hline & & & Addr & ss of res & spondents & & \\
\hline & & & Nepal & India & Bangladesh & lotal & \\
\hline \multirow{6}{*}{ 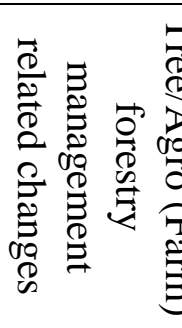 } & \multirow{3}{*}{$\begin{array}{c}\text { No } \\
\text { changes }\end{array}$} & Count & 104 & 112 & 62 & 278 & \multirow{9}{*}{$\begin{array}{c}\text { Value= } \\
46.047 \\
\text { Df }=2 \\
\text { Asymp. } \\
\text { Sig. (2- } \\
\text { sided) } \\
.000 \\
(\mathrm{~S})\end{array}$} \\
\hline & & $\%$ within total & $37.4 \%$ & $40.3 \%$ & $22.3 \%$ & $100.0 \%$ & \\
\hline & & $\%$ within address & $74.3 \%$ & $80.0 \%$ & $44.3 \%$ & $66.2 \%$ & \\
\hline & \multirow{3}{*}{$\begin{array}{c}\text { Some } \\
\text { changes }\end{array}$} & Count & 36 & 28 & 78 & 142 & \\
\hline & & $\%$ within total & $25.4 \%$ & $19.7 \%$ & $54.9 \%$ & $100.0 \%$ & \\
\hline & & $\%$ within address & $25.7 \%$ & $20.0 \%$ & $55.7 \%$ & $33.8 \%$ & \\
\hline \multirow{3}{*}{\multicolumn{2}{|c|}{ Total }} & Count & 140 & 140 & 140 & 420 & \\
\hline & & $\%$ within total & $33.3 \%$ & $33.3 \%$ & $33.3 \%$ & $100.0 \%$ & \\
\hline & & $\%$ within address & $100.0 \%$ & $100.0 \%$ & $100.0 \%$ & $100.0 \%$ & \\
\hline
\end{tabular}

Vol. 2. No. II

www.phdcentre.edu.np 
ISSN: 2362-1303 (Paper) | eISSN: 2362-1311(Online)

JOURNAL OF ADVANCED ACADEMIC RESEARCH (JAAR)

July 2015

Sources: Field study, 2013

In Nepal, the results show that $74.3 \%$ of households had made no changes on agro forestry management related changes in the last decade. Only $25.7 \%$ of households had made Some Tree/ Agro forestry related changes. In India, $80 \%$ household followed by $44.3 \%$ of Bangladesh had made no changes on agro forestry. There was significant association $(\mathrm{p}=.000)$ found between the respondents of 3 countries regarding the tree/agro forestry management related changes.

\section{DISCUSSION}

The findings clearly indicate that the climate change directly influences on land and water management. The impact is very much obvious in all the three South Asian countries namely, Nepal, India and Bangladesh. Many studies have explained similar results in other countries as well. The study shows that ethnicity or religious beliefs have no preference on causing such impacts.

The effect on the soil water conditions in the fragile ecosystems of these three countries having higher and lower altitudes is even more precarious. Because of the poor soil and water quality, there is a great concern on agriculture and food security issues. These have resulted in some changes in cropping pattern as the rainfall pattern is changing. Overall, change in temperature has both direct and indirect impact to the gross domestic product (Bhatta, 2013). The study provides an opportunity to understand the impacts on agriculture systems through the change in farming scenarios of the areas studied. The study is based on the knowledge, skills and practices of the farming communities of these three countries. As most of the farming in Nepal, India and Bangladesh depends on monsoon, change in climate has enormous impact on the soil water situations and thus on the food security of the small farmers of these regions. The fragile ecosystems of these areas are significantly affected. It is well known that the poor farmers of the poor countries are more exposed to such factors such as in agriculture and water resources (ICMCCC, 2012). Furthermore, these poorer countries tend to be hotter and therefore closer to the biophysical temperature limits. Against such scenarios in Nepal, India and Bangladesh, the general development works needs to be geared towards the adaptation. The requirement for the adaptation work in these countries is high, but there is little knowledge on what exactly is the value being added by the adaptation as such for reducing vulnerability apart from poverty alleviation. This demands an exploration of possible mainstreaming approach of adaptation to the general development at local level.

The rural poor population in these three countries is more vulnerable due to the degradation of the soil and water quality as their livelihood options are dependent on such natural resources, which are further exposed physically to the variation of the climate change. For example temperature rise was found to affect the high altitude region like Himalaya considerably more as the surrounding ecosystem are linked to snow cover that is melting. Vol. 2. No. II

www.phdcentre.edu.np 
ISSN: 2362-1303 (Paper) | eISSN: 2362-1311(Online)

JOURNAL OF ADVANCED ACADEMIC RESEARCH (JAAR)

July 2015

Similarly, ever increasing water salinity problem in the coastal regions of Bangladesh has threatened to wipe out the livelihood of the local people. Such local communities that are completely dependent on the natural resources since time immemorial residing in such regions are highly vulnerable to such change effects.

It is notable that all these countries have rising population which has put additional pressures on the natural resources that clearly show the degradation of the soil and water conditions impacting on the agriculture and food security in their community. Small farmers of all these countries have been or still are facing farming problems. All these countries depend upon almost similar food crops and birds and animals for their livelihood since ages. Soil water degradation has a profound impact on all these.

Culturally speaking, all these communities are very close to each other in terms of their food habits, social and gender perspectives, farming perception, rural poverty and livelihood options. However, with all these similarities, the locations also show a distinct difference in terms of the impacts of climate change. Nepal has more snow melting due to global warming resulting in soil and water erosions. Indian planes using more green revolution technologies would have degradation of soil and water quality including deepening ground water level. Whereas, the coastal area of Bangladesh distinctly show the sea water rising due to global warming resulting in inland sea water that has caused havoc due to ever increasing salinity problems.

The study sites are facing the problem of climate change which in turn causing land and water degradation and food insufficiency resulting to a number of problems. The findings revealed that climate change directly affects to the well being of the community as it directly affects on land and water on which their life depends.

\section{CONCLUSIONS}

This study revealed the situations against the climate change perspectives and its impacts on land and water resources. Data show that majority of the respondents believed that climate change has been affecting on the land and water system. The respondents overwhelmingly reported that there was no change in water management system in Nepal but the situation was different in India and Bangladesh. However, majority of the respondents found changes in soil management and agro forestry practices because of the climatic change factors in all the three countries.

\section{ACKNOWLEDGEMENT}

I would like to thank CEAPRED (Center for Environmental and Agricultural Policy Research, Extension and Development), Kathmandu for supporting my studies in the three South Asian Countries. My special appreciation and thanks go to Dr. Hari Krishna Upadhyaya, Executive Chairman of CEAPRED for his full support including financial, administrative and Vol. 2. No. II 
ISSN: 2362-1303 (Paper) | eISSN: 2362-1311(Online)

JOURNAL OF ADVANCED ACADEMIC RESEARCH (JAAR) July 2015

moral. I would also like to acknowledge the similar support of CCAFS (Climate Change, Agriculture and Food Security) at Nairobi and New Delhi, thanking specially to Mrs. Wiebke at Nairobi and to Dr. Pramod Agrawal and Dr. Gopal Bhatta at Delhi Office for making this work possible.

I also thank Mr. Ganesh Acharya, Mrs. Laxmi Khadka, Mr. P. R. Neupane and Miss Isha Gharti of CEAPRED in for their help in all sites. Similarly, I am also thankful to Dr. RKP Sigh and Mr. Aminur Rahaman for their support in India and Bangladesh sites respectively.

Lastly, I also like to thank Mr. Tej Bahadur Karki of PhD Center, Kathmandu for his help.

\section{REFERENCES}

Bhatta, S. P. (2013). Impact of climate change on agricultural growth in Nepal . NRB Economic Review , 1-16.

CSIRO (2008). An overview of climate change adaptation in Austalian primary industries impacts, options and priorities . Australia : CSIRO.

ICMCCC (2012). Kathmandu Call for Action. International Conference of Mountain Countries on Climate Change (p. 2). Kathmandu: ICMCCC Conference Secretariat.

IPCC (2007). Climate Change 2007: Impacts, Adaptation and Vulnerability - Contribution of Working Group II to the Fourth Assessment Report of the Intergovernmental Panel on Climate Change. Cambridge, UK: Cambridge University Press.

John Reilly, S. P. (2007). Global Economic Effects of Changes in Crops, Pasture, and Forests due to Changing Climate, Carbon Dioxide and Ozone. USA: MIT.

M. L. Parry, C. R. (2004). Effects of climate change on global food production under SRES emissions and socio-economic scenarios. Global Environmental Change (14), 53-67.

Stern, N. (2006). Ecomonics of Climate Change: The Stern Review. Cambridge: Cambridge University Press.

UNFCC. (2007). Climate change - impacts, vulnerabilities and adaptation in developing countries. Germany : United Nations Framework Convention on Climate Change . 